\title{
メヒカリの栄養成分
}

水野時子 · 山田幸二

(郡山女子大学短期大学部)

\section{Nutritional components of greeneye (Chlorophthalmus albatrossis)}

\author{
Tokiko Mizuno, Koji Yamada
}

Koriyama Women's Junior College, 3-25-2, Kaisei Koriyama, Fukushima, 963-8503

干963-8503 福島県郡山市開成 3-25-2

We investigated the nutritional components of greeneye, the official fish of Iwaki city, Fukushima Prefecture, using specimens from different fishing grounds (in Aichi Prefecture and Miyazaki Prefecture and offshore of Joban).

1. The nutritional components were as follows: water, 66.6-75.2\%; protein, $14.2-$ 15.8\%; lipids, 5.4-14.9\%; ash, 2.6-3.6\%. Differences among the fishing grounds were particularly significant for the lipid content.

2 . The limiting amino acid was tryptophan, and the amino acid score was 83 .

3 . The primary free amino acids were lysine, taurine, alanine, leucine, and glutamate. The total free amino acid content varied among the fishing grounds. In addition, compared to other amino acids, the taurine content was significantly affected by cooking.

4. The fatty acid composition of the lipids mainly included palmitic acid (approximately 24\%), oleic acid (approximately 42\%), icosapentaenoic acid (EPA; approximately $6 \%$ ), and docosahexaenoic acid (DHA; approximately 10\%), indicating a high proportion of oleic acid.

5 . For the whole body, the cholesterol and taurine contents decreased when the head and viscera were removed.

\section{1. 緒言}

近年わが国では，平均寿命の延長や食生活の向上とと もに健康志向が高まり，食品の健康機能に対する関心が 高い。日本人の食生活の特徴は, 魚介類の摂取量が多い ことである。魚の摂取量や摂取頻度は, 疾病の発症率の 低減 ${ }^{1)}$ や死亡率の低下 $\left.{ }^{2}{ }^{3}\right)$ に関与することが報告されて いる。また魚油に多く含まれている $\mathrm{n}-3$ 多価不飽和脂 肪酸，すなわちイコサペンタエン酸 $\left(\mathrm{C}_{20}:{ }_{5} \mathrm{EPA}\right)$, ドコ サヘキサエン酸（C22:6DHA）は脳卒中（脳梗塞）予防 作用 ${ }^{4)}$, 血中脂質低下作用 ${ }^{5}$ 等のあることが知られている。 福島県いわき市では2001年に，市民に親しまれている ことからメヒカリ（写真1）を「市の魚」に制定した。 メヒカリは青森県から鹿児島県にいたる大陸棚斜面上部 の水深100～450m海域に生息するアオメエソ科の底生魚 で，標準和名はアオメエソ (Chlorophthalmus albatros- sis）である。漁獲は周年行われ, 漁況にも影響されるが 平均して10月～12月の冬場に多い ${ }^{6)}$ 。体長 $15 \mathrm{~cm}$ ほどの 小型魚であり, 肉質は白色で魚肉, 骨とともに脆弱であ

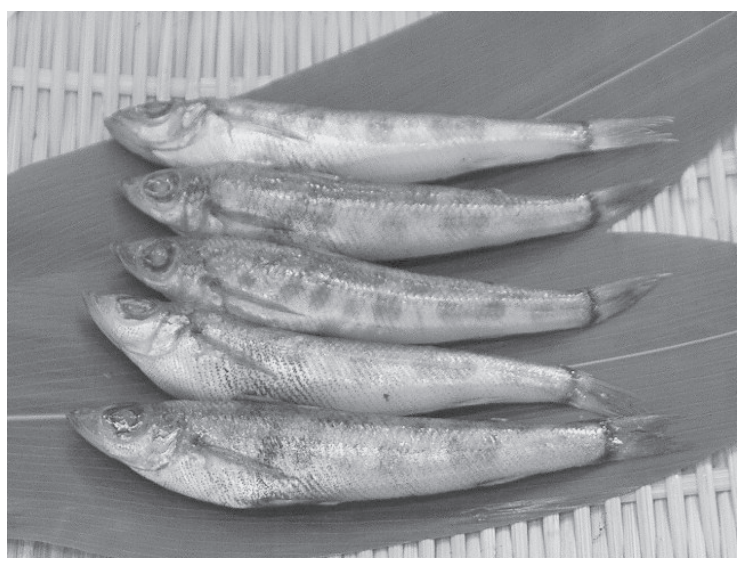

写真 1 
る。そのため，頭部と内臟を除去せずに魚体全体を調理 に用い食されることが多い。しかし，メヒカリの生態は 十分に解明されておらず，また漁獲海域の異なるメヒカ リを用いての栄養成分についての報告はあまり見られな い。そこで，漁獲海域の異なるメヒカリを用いて，メヒ カリの一次機能（栄養的機能）成分，二次機能（嗜好的 機能）成分，三次機能（生理的機能）成分を，同時期に 市場に出回り日本人に食されることの多いイワシ, アジ, サンマと比較し検討した。また, 調理による遊離アミ) 酸組成の変動を検討した。

\section{2. 実験方法}

\section{1) 実験試料}

実験に用いたメヒカリ（愛知県産，宮崎県産，常磐沖 産)，イワシ，アジ，サンマは 9〜10月にかけて郡山市 内の大手スーパー，扔よび魚市場より入手した。メヒカ リ，イワシは丸ごと食することから魚体全体，アジとサ ンマは頭と内臟を取り除き食べることが多いので頭と内 臟を除いてヒスコトロン（日音医理科機械製造所製）を 用いホモジネートし分析に供した。メヒカリの調理は魚 体全体を用い，(1)500ワットの電子レンジで 3 分間加熱 調理（電子レンジ), (2) $200^{\circ} \mathrm{C}$ の電気オーブンで 8 分間加 熱調理（オーブン），(3)植物油を用いての素揚げ調理（素 揚げ），(4)片栗粉をまぶし植物油を用いて揚げたから揚 げ（から揚げ），(5薄力粉：水 $=1 ： 2$ (重量比）の衣 をつけて植物油で揚げた天ぷら（天ぷら），(6)薄力粉・ 全卵・パン粉の順に付けて植物油で揚げたフライ（フラ イ）を行った。(3)〜 (6)は日立天ぷらなべNT-110を用い 設定温度 $180^{\circ} \mathrm{C} て ゙ 2$ 分間調理した。

\section{2) 分析方法}

水分は $105^{\circ} \mathrm{C}$ 常圧加熱乾燥法 ${ }^{7)}$, タンパク質はケルダー ル法7)によって窒素を測定し6.25を乗じて算出，脂質は クロロホルム：メタノール（2：1）の混液を溶媒とし て用い Folch 法 $^{8)}$ に準じて抽出し重量法，灰分は $550^{\circ} \mathrm{C}$ 直接灰化法 ${ }^{8)} に よ り$ 求めた。ミネラル組成は，乾式灰化
後塩酸抽出を行い ICP 発光分析法により求めた。タン パク質構成のアミノ酸組成の分析は, 真空下に打いて 6 $\mathrm{N}$ 塩酸により $110^{\circ} \mathrm{C}$ で24時間加水分解後, 一定量とし $\mathrm{JLC} / \mathrm{V}$ （日本電子株式会社）を用いて行った。シスチン およびメチオニンはギ酸により分解後， $6 \mathrm{~N}$ 塩酸により $150^{\circ} \mathrm{C}$ で20時間加水分解しシスチン酸拉よびメチオニン スルホンとして測定した。トリプトファンは水酸化バリ ウムにより加水分解後, 高速液体クロマトグラフ（カラ ム：ジーエルサイエンス侏製 Inertsil ODS- 2，（申4.6 $\mathrm{mm} \times 250 \mathrm{~mm}$ ）を用いて測定した。

遊離アミノ酸組成は, 試料の 40 倍量の $1 \%$ ピクリン酸 を加え, 超高速万能ホモジナイザーを用いホモジナイズ と除タンパク質を行い，その上清を Dowex- $2, \mathrm{X}-8$ の カラムによりピクリン酸を除去し蒸発乾固後, $\mathrm{pH} 2.2$ の クエン酸緩衝液で一定量とし分析に供した。アミノ酸の 分析は日立 L-8800形の高速アミノ酸自動分析計を用い 生体液分析法で行った。調理品については，衣をつけた 状態で分析に用いた。コレステロールは，ケン化したの ち Z a k 法 ${ }^{9)} に よ り$ 測定した。脂質中の脂肪酸組成は, Folch 法 $^{8)}$ によって抽出した脂質を 5 \% 塩酸メタノール でメチルエステル化し日立製 G-3500型ガスクロマトグ ラフィーで分析した。な挍，分析はキャピラリーカラム （CP-sill 88， for FAME $50 \mathrm{~m} \times 0.25 \mathrm{~mm} ）$ を用い，カラ 厶温度 $190^{\circ} \mathrm{C}$, 注入口温度 $270^{\circ} \mathrm{C}$, ディテクター温度 $300^{\circ} \mathrm{C}$ の条件で行った。実験結果の有意差の検定は，一 次項分散分析（エクセル統計2006）にて行った。

\section{3．実験結果および考察}

\section{1）メヒカリの一般成分}

魚類の一般成分を表 1 , タンパク質のアミノ酸組成を 表 2 , 必須アミノ酸パターン（学童期前 $2-5$ 歳 $/ 1985$ 年 $\mathrm{FAO} / \mathrm{WHO} / \mathrm{UNU})$ に対するアミノ酸の割合とアミノ 酸スコアを表 3 ，無機質組成を表 4 にそれぞれ示した。

メヒカリのタンパク質含量は, 愛知県産 $14.2 \%$, 宮崎 県産15.8\%，常磐沖産14.3\%で漁獲海域の違いにより統

表 1 魚類の一般成分（\%)

\begin{tabular}{|c|c|c|c|c|c|c|c|c|c|c|c|c|}
\hline & \multicolumn{3}{|c|}{ 水分 } & \multicolumn{3}{|c|}{ タンパク質 } & \multicolumn{3}{|c|}{ 脂質 } & \multicolumn{3}{|c|}{ 灰分 } \\
\hline \multicolumn{13}{|l|}{ メヒカリ1) } \\
\hline 愛知県産（n= 5） & 66.6 & \pm & $\left.1.5^{3)} \mathrm{c} 4\right)$ & 14.2 & \pm & $0.4^{\mathrm{b}}$ & 14.9 & \pm & $1.9^{\mathrm{a}}$ & 2.6 & \pm & 0.3 \\
\hline 宮崎県産（n= 5） & 75.2 & \pm & $1.4^{\mathrm{a}}$ & 15.8 & \pm & $0.3^{\mathrm{a}}$ & 5.4 & \pm & $1.4^{\mathrm{c}}$ & 3.6 & \pm & 0.9 \\
\hline 常磐沖産（n= 5） & 70.3 & \pm & $1.3^{\mathrm{b}}$ & 14.3 & \pm & $0.3^{b}$ & 11.2 & \pm & $1.2^{\mathrm{b}}$ & 2.8 & \pm & 0.2 \\
\hline 平 均 $(\mathrm{n}=15)$ & 71.0 & \pm & 4.2 & 14.8 & \pm & 0.8 & 10.5 & \pm & 4.2 & 3.0 & \pm & 0.7 \\
\hline イワシ $(\mathrm{n}=5)^{1)}$ & 64.8 & \pm & 2.2 & 18.2 & \pm & 0.5 & 11.5 & \pm & 1.8 & 3.8 & \pm & 0.5 \\
\hline サンマ $(\mathbf{n}=5)^{2)}$ & 56.7 & \pm & 2.0 & 18.0 & \pm & 0.8 & 19.2 & \pm & 1.6 & 1.5 & \pm & 0.2 \\
\hline アジ $(\mathbf{n}-5)^{2)}$ & 70.8 & \pm & 2.6 & 19.2 & \pm & 0.7 & 9.5 & \pm & 1.7 & 1.8 & \pm & 0.3 \\
\hline
\end{tabular}

1）魚体全体を試料として分析した

$2 ）$ 頭と内臓を除去し分析した

3 ) 平均土標準偏差

4） a, b, c の異なった記号はメヒカリの漁獲海域において有意差があることを示す（p＜0.05） 
表 2 魚類タンパク質のアミノ酸組成 $(\mathrm{mg} / \mathrm{g}$ タンパク質)

\begin{tabular}{lrrrr}
\hline & メヒカリ & マイワシ & サンマ & アジ \\
\hline イソロイシン & 40 & 46 & 46 & 47 \\
ロイシン & 71 & 79 & 78 & 80 \\
リジン & 77 & 90 & 88 & 93 \\
メチオニン & 29 & 29 & 32 & 31 \\
シスチン & 8 & 10 & 11 & 11 \\
フェニルアラニン & 41 & 41 & 40 & 42 \\
チロシン & 29 & 33 & 34 & 35 \\
スレオニン & 41 & 46 & 46 & 47 \\
トリプトファン & 9 & 11 & 11 & 11 \\
バリン & 46 & 53 & 52 & 52 \\
ヒスチジン & 23 & 51 & 58 & 41 \\
アルギニン & 48 & 56 & 56 & 59 \\
アラニン & 64 & 60 & 58 & 60 \\
アスパラギン酸 & 92 & 98 & 97 & 100 \\
グルタミン酸 & 135 & 140 & 130 & 140 \\
グリシン & 61 & 48 & 48 & 47 \\
プロリン & 40 & 34 & 35 & 36 \\
セリン & 39 & 39 & 39 & 40 \\
\hline
\end{tabular}

1）宮崎県産，魚体全体を試料として分析した。

メヒカリ以外の魚は改訂 日本食品アミノ酸組成表值を引用した

表 3 メヒカリの必須アミノ酸パターンに対する割合とアミノ 酸スコア

\begin{tabular}{lrr}
\hline 必須アミノ酸 & $\begin{array}{r}\text { 評点パターン* } \\
(\mathrm{mg} / \mathrm{g} \text { タンパク質 })\end{array}$ & メヒカリ \\
\hline イソロイシン & 28 & 141 \\
ロイシン & 66 & 108 \\
リジン & 58 & 132 \\
含硫アミノ酸 & 25 & 150 \\
(メチオニン+シスチン) & & \\
芳香族アミノ酸 & 63 & 111 \\
(フェルアラニン+チロシン) & & \\
スレオニン & 34 & 120 \\
トリプトファン & 11 & 83 \\
バリン & 35 & 130 \\
ヒスチジン & 19 & 119 \\
\hline アミノ酸スコア & \multicolumn{2}{c}{83} \\
第1制限アミノ酸 & \multicolumn{2}{c}{} \\
\hline
\end{tabular}

*「アミノ酸評点パターン (学童期前 $2-5$ 歳 $) 」$

(1985年 FAO/WHO/UNU 合同専門家協議会報告)。

計的な有意差は認められたが変動幅は小さかった。魚類 のタンパク質含量は，魚種やその年齢などによって異な るが，水分や脂質含量に比べ季節変動はほとんどみられ

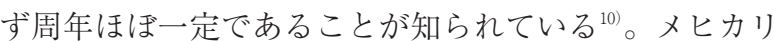
のタンパク質含量も大きな季節変動は見られず15\%前後 のタンパク質を含有していることが報告 ${ }^{11) ~ 13) さ れ て い る 。 ~}$ 本研究とあわせ考えると，メヒカリのタンパク質含量は 漁獲海域による変動は小さくまた周年約 $15 \%$ で，試料部 位が同じ条件でないことから比較は必ずしも適正ではな いが, イワシの $18.2 \%$ ，サンマの18.0\%，アジの19.2\%

\begin{tabular}{lc} 
表 4 メヒカリの無機質組成 $(\mathrm{mg} / 100 \mathrm{~g})$ \\
\hline
\end{tabular}

に比べて若干低值であることが示された。しかし，乾物 換算值ではメヒカリ全体で51.0\%，イワシ51.7\%，サン マ41.6\%，アジ65.8\%で，アジより低值であったがイワ シと同程度でサンマより高值を示した。

メヒカリのタンパク質中のアミノ酸組成は, グルタミ ン酸 $(\mathrm{Glu})$, アスパラギン酸 (Asp), リジン (Lys), ロイシン (Leu) が高值で, シスチン, トリプトファン （Trp）が低值であった。イワシ，アジ，サンマのアミ ノ酸組成と比較し，ヒスチジン（His）は低值ではあっ たが類似したアミノ酸組成を示した。魚介類の筋肉夕ン パク質中のアミノ酸組成は，魚種間に差はほとんど見ら れず比較的一定であることが知られており ${ }^{14)}$ ，メヒカリ も例外ではないことが示された。必須アミノ酸パターン に対するメヒカリのアミノ酸の割合は，Trp 以外の必須 アミノ酸はいずれも100を越え，アミノ酸スコアは83で Trp が制限アミノ酸であった。魚類のアミノ酸スコアは 100ないし100に近いが, マダイ, サバのアミノ酸スコア 
はそれぞれ97，99で制限アミノ酸はメヒカリと同じTrp であることが報告されている ${ }^{15)}$ 。しし，主食であるコ メや小麦タンパク質に少ない Lys 含量が他の魚と同様 に高かった。

メヒカリの脂質含量は, 宮崎県産 $5.4 \%<$ 常磐沖産 $11.2 \%<$ 愛知県産 $14.9 \%$ ダタパク質, 灰分に比べて漁 獲海域による大きな変動が見られた。また水分含量は宮 崎県産 $75.2 \%>$ 常船沖産70.3\%>爱知県産 $66.6 \%$ で，脂 質含量と水分含量には逆の関係が見られた。魚類の脂質 含量は同一種でも季節，年齢生殖腺熟度などによって大 きく変動すること, 脂質が蓄積する季節には水分が減少 し脂質が減少する時期には水分が増加し，両者の和が $80 \%$ 前後になる場合が多いことが知られている年。メヒ カリの脂質含量も季節変動が見られ特に秋に脂質含量が 高いこと ${ }^{13)}$, 魚体全長と脂質含量との間に高い相関を示 すこと ${ }^{15)}$ が報告されている。さらに本報告の結果，漁獲 海域の異なるメヒカリも脂質と水分の和が愛知県産は $81.5 \%$ ，宮崎県産は $80.6 \%$ ，常磐沖産は $81.5 \%$ であた。 メヒカリの脂質含量は，タンパク質と同様に試料部位が 同じでないことから比較するには問題もあるが, 同時期 に漁獲されたサンマの $19.2 \%$ に比べ低值で同じ白身の魚 で底棲魚であるヒラメの $2.0 \%$ （5 訂日本食品標準成分 表值）に比べ高值であった。

メヒカリのコレステロール（Chol）含量は，表とし て示してはいないが魚体全体を試料とした場合 $210 \mathrm{mg} / 100 \mathrm{~g}$ ，頭と内臓を除去した場合 $187 \mathrm{mg} / 100 \mathrm{~g}$ で あった。魚体全体を試料としたメヒカリの Chol 含量は, 魚体丸ごと食するシシャモ $230 \mathrm{mg} / 100 \mathrm{~g}$ ，ワカサギ $210 \mathrm{mg} / 100 \mathrm{~g}$ （5 訂日本食品標準成分表值）と同程度で あったが，頭と内臓を取り除くことにより約 $89 \%$ に減少 した。

メヒカリの灰分含量は，2.6３.6\%（平均3.0\%）で 漁獲海域による統計的な差は認められなかった。魚体全 体を用いたメヒカリの $3.0 \%$ とイワシの $3.8 \%$ は頭と内臓 を除去したサンマの1.5\%, アジの1.8\%に比べて高值で, 骨や内臓も含めて 1 尾丸ごと食する魚は灰分を多量に攝 取することが出来る。メヒカリのカルシウム $(\mathrm{Ca})$ 含 量は662mg/100gで，メヒカリと同様に魚体全体を食す るシシャモ330mg/100g，ワカサギ450mg/100g（5 訂日 本食品標準成分表值）と比べても 1.5～2 倍の Ca を含 有していた。国民健康・栄養調査結果による Ca捸取量は, 「日本人の食事摂取基準」の目標量を満たしていないこ とから，現代はメヒカリのような $\mathrm{Ca}$ 含量の高い食品の 摂取が望まれる。メヒカリの鉄 $(\mathrm{Fe})$ 含量は $3.0 \mathrm{mg}$ $/ 100 \mathrm{~g}$ で，Fe を含むへムタンパク質に富むため Fe 含量 が高いカツオ $1.9 \mathrm{mg} / 100 \mathrm{~g}$ やマグロ $1.1 \mathrm{mg} / 100 \mathrm{~g}$ （5 訂 日本食品標準成分表值）よりも含量が高かった。Feも $\mathrm{Ca}$ と同じく摂取不足傾向にある無機質であり，不足に より貧血や運動機能の低下，認知機能などの低下を招く ことが知られている ${ }^{16)}$ 。メヒカリの亜鉛 $(Z n)$ 含量は
$1.8 \mathrm{mg} / 100 \mathrm{~g}$ であった。近年日本では $\mathrm{Ca}, \mathrm{Fe}$ 以外の微 量元素では Zn の欠乏による味覚などの感覚異常, 成長 遅延，食欲不振などが知られている ${ }^{16)}$ 。 $Z n$ は皮膚や骨， 内臓に多い（5 訂日本食品標準成分表值）ので，1 尾丸 ごと食すことの出来るメヒカリは貴重な供給源と考えら れる。

\section{2 ）メヒカリの遊離アミノ酸組成}

メヒカリ，イワシ，サンマ，アジの遊離アミノ酸組成 を表 5 に示した。

メヒカリの遊離アミノ酸総量は, 愛知県産 $<$ 常磐沖産 <宮崎県産の順に高值を示し漁獲海域により統計的な有 意差が認められた。宮崎県産は，爱知県産，常磐沖産に 比ベて Asp, セリン (Ser), グルタミン $(\mathrm{Gln})$, チロシ ン (Tyr), His, アンセリン (Ans： $\beta$-アラニル-L-ヒス チジン), アルギニン $(\operatorname{Arg})$ 以外のアミノ酸が高值であっ た。しかし，個々のアミノ酸の遊離アミノ酸総量に占め る割合は Arg を除き漁獲海域による大きな違いは見ら れなかった。A $\mathrm{Ag}$ は愛知県産, 宮崎県産に対して常磐沖 産が顕著に高值を示し，遊離アミノ酸総量に占める $\mathrm{Arg}$ の割合は愛知県沖産 $3.5 \%$, 宮崎県産 $2.1 \%$ に比べて常磐 沖産10.8\%で高く漁獲海域による違いが見られた。

メヒカリの主要な遊離アミノ酸は，どの漁獲海域にお いても Lys, タウリン (Tau) で, 次いでアラニン (Ala), Leu, Gluであった。久留ら ${ }^{13)}$ の周年メヒカリで含量が 高い遊離アミノ酸の報告と一致していた。イワシ，サン マ，アジの遊離アミノ酸組成が His に著しく偏っている のに対して, メヒカリは Gln, $\gamma$-アミノ酪酸, オルニ チンの他は概して平均的であった。魚介類の遊離アミノ 酸組成は, タンパク質中のアミノ酸組成と異なり魚種間 に大きな違いが見られることが知られている ${ }^{14)}$

食品に含まれる遊離アミノ酸は，呈味性との関わりが 指摘され, 食品の嗜好的価值を左右するのに大切な役割 を果たしている ${ }^{17)}$ 。特に，魚介類の味に大きく関与する ことが報告 ${ }^{18)}$ されている Glu, Ala, Arg は, メヒカリの どの漁獲海域においてもイワシに比べて低值であったが, アジ，サンマに比べて高值であった。メヒカリは官能評 価により，遊離アミノ酸の増加する夏（ 6 月下旬〜 7 月 上旬）および脂質含量の最も高い秋（10月上旬）に美味 であることが報告されている ${ }^{13)}$

近年, 生体内において個々のアミノ酸が独自の生理機 能を発揮することが明らかになってきた ${ }^{17}$ 。 BCAA（分 岐鎖アミノ酸：バリン・Leu・イソロイシンの総量）は エネルギー活性化等，Argは成長ホルモン分泌促進作用 等, ジペプチドであるAns やカルノシン（ $\beta$-アラニル -L-ヒスチジン）は抗酸化作用等，Gln は胃粘膜保護作 用・免疫活性化機能等が報告 ${ }^{17)}$ されている。メヒカリの BCAA，Arg，Ans，Gln含量は，どの漁獲海域において もイワシに比べて低值であったがサンマやアジに比較し て高值であった。

一般に魚介類に多くコレステロール上昇抑制作用や肝 
メヒカリの栄養成分

表 5 魚類の遊離アミノ酸組成（mg/100g dry matter basis, 漁獲月 9 月）

\begin{tabular}{|c|c|c|c|c|c|c|c|c|c|c|c|c|c|c|c|}
\hline \multirow{3}{*}{ タウリン } & \multicolumn{15}{|c|}{ メヒカリ1) } \\
\hline & \multicolumn{3}{|c|}{ 愛知県産（n=5） } & \multirow{2}{*}{$\begin{array}{c}\frac{(\%)^{4)}}{11.9} \\
\end{array}$} & \multicolumn{2}{|c|}{ 宮崎県産 } & $(n=5)$ & \multirow{2}{*}{$\begin{array}{c}\%) \\
7.9\end{array}$} & \multicolumn{2}{|c|}{ 常磐沖産 } & $(n=5)$ & \multirow{2}{*}{$\begin{array}{c}\%) \\
6.5\end{array}$} & \multirow{2}{*}{$\begin{array}{c}\text { 平均 } \\
198.1\end{array}$} & $(n=15)$ & $(\%)$ \\
\hline & 172.3 & \pm & $16.8^{3 / \mathrm{b} 5)}$ & & 276.8 & \pm & $30.1^{a}$ & & 145.1 & \pm & $7.8^{\mathrm{b}}$ & & & 60.3 & 8.3 \\
\hline アスパラギン酸 & 46.9 & \pm & $7.0^{\mathrm{b}}$ & 3.2 & 76.6 & \pm & $24.3^{\mathrm{a}}$ & 2.2 & 81.5 & \pm & $4.4^{\mathrm{a}}$ & 3.7 & 68.3 & 21.3 & 2.9 \\
\hline スレオニン & 64.6 & \pm & $12.8^{\mathrm{b}}$ & 4.5 & 164.1 & \pm & $35.6^{\text {a }}$ & 4.7 & 85.8 & \pm & $2.5^{\mathrm{b}}$ & 3.9 & 104.8 & 48.1 & 4.4 \\
\hline セリン & 48.2 & \pm & $7.5^{\mathrm{b}}$ & 3.3 & 83.0 & \pm & $14.9^{\mathrm{a}}$ & 2.4 & 86.7 & \pm & $3.7^{\mathrm{a}}$ & 3.9 & 72.6 & 20.0 & 3.0 \\
\hline グルタミン酸 & 120.4 & \pm & $22.4^{b}$ & 8.3 & 337.7 & \pm & $73.3^{\mathrm{a}}$ & 9.7 & 149.1 & \pm & $5.7^{\text {b }}$ & 6.7 & 202.4 & $\pm \quad 106.1$ & 8.5 \\
\hline グルタミン & 12.1 & \pm & $2.5^{\mathrm{b}}$ & 0.8 & 40.9 & \pm & $13.1^{\mathrm{a}}$ & 1.2 & 32.1 & \pm & $3.0^{\mathrm{a}}$ & 1.4 & 28.4 & 14.4 & 1.2 \\
\hline グリシン & 38.2 & \pm & $3.5^{\mathrm{b}}$ & 2.6 & 115.3 & \pm & $20.9^{\mathrm{a}}$ & 3.3 & 56.3 & \pm & $3.9^{\mathrm{b}}$ & 2.5 & 69.9 & 35.2 & 2.9 \\
\hline アラニン & 120.3 & \pm & $18.5^{\mathrm{b}}$ & 8.3 & 344.7 & \pm & $64.6^{\mathrm{a}}$ & 9.9 & 153.8 & \pm & $7.5^{\mathrm{b}}$ & 6.9 & 206.3 & $\pm \quad 106.3$ & 8.7 \\
\hline バリン & 61.1 & \pm & $10.9^{\mathrm{b}}$ & 4.2 & 208.0 & \pm & $49.4^{\mathrm{a}}$ & 6.0 & 96.6 & \pm & $7.3^{\mathrm{b}}$ & 4.4 & 121.9 & 69.2 & 5.1 \\
\hline メチオニン & 44.6 & \pm & $8.9^{b}$ & 3.1 & 146.1 & \pm & $39.1^{\text {a }}$ & 4.2 & 82.4 & \pm & $9.8^{\mathrm{b}}$ & 3.7 & 91.0 & 48.2 & 3.8 \\
\hline イソロイシン & 51.8 & \pm & $11.0^{\mathrm{b}}$ & 3.6 & 177.1 & \pm & $42.4^{\mathrm{a}}$ & 5.1 & 69.4 & \pm & $10.3^{\mathrm{b}}$ & 3.1 & 99.4 & 61.2 & 4.2 \\
\hline ロイシン & 102.1 & \pm & $21.4^{\mathrm{b}}$ & 7.1 & 329.0 & \pm & $84.8^{a}$ & 9.4 & 182.3 & \pm & $23.2^{\mathrm{b}}$ & 8.2 & 204.5 & $\pm \quad 107.5$ & 8.6 \\
\hline チロシン & 41.7 & \pm & $10.0^{\mathrm{b}}$ & 2.9 & 75.4 & \pm & $16.2^{\mathrm{a}}$ & 2.2 & 82.0 & \pm & $14.5^{\mathrm{a}}$ & 3.7 & 66.4 & 22.4 & 2.8 \\
\hline フェニルアラニン & 56.1 & \pm & $10.5^{\mathrm{b}}$ & 3.9 & 169.0 & \pm & $42.4^{\mathrm{a}}$ & 4.8 & 81.4 & \pm & $16.8^{\mathrm{b}}$ & 3.7 & 102.2 & 55.4 & 4.3 \\
\hline$\beta$-アラニン & 7.3 & \pm & $1.6^{\mathrm{c}}$ & 0.5 & 24.0 & \pm & $1.3^{\mathrm{a}}$ & 0.7 & 12.6 & \pm & $1.9^{b}$ & 0.6 & 14.7 & 7.1 & 0.6 \\
\hline$\gamma$-アミノ酪酸 & 3.6 & \pm & $1.8^{\mathrm{ab}}$ & 0.2 & 8.3 & \pm & $4.0^{\mathrm{a}}$ & 0.2 & 1.8 & \pm & $0.1^{\mathrm{b}}$ & 0.1 & 4.6 & 3.7 & 0.2 \\
\hline オルニチン & 11.7 & \pm & $2.6^{\mathrm{b}}$ & 0.8 & 43.9 & \pm & $5.1^{\text {a }}$ & 1.3 & 10.6 & \pm & $1.1^{\mathrm{b}}$ & 0.5 & 22.1 & 15.8 & 0.9 \\
\hline リジン & 204.0 & \pm & $42.7^{\mathrm{c}}$ & 14.1 & 411.3 & \pm & $69.1^{\text {a }}$ & 11.8 & 300.1 & \pm & $19.4^{\mathrm{b}}$ & 13.5 & 305.1 & 97.5 & 12.8 \\
\hline 1-メチルヒスチジン & 8.9 & \pm & $1.7^{\mathrm{c}}$ & 0.6 & 35.3 & \pm & $3.1^{\mathrm{a}}$ & 1.0 & 18.8 & \pm & $2.2^{\mathrm{b}}$ & 0.8 & 21.0 & 11.1 & 0.9 \\
\hline ヒスチジン & 36.7 & \pm & $9.4^{\mathrm{b}}$ & 2.5 & 84.4 & \pm & $10.2^{\mathrm{a}}$ & 2.4 & 74.9 & \pm & $7.0^{\mathrm{a}}$ & 3.4 & 65.4 & 22.5 & 2.7 \\
\hline アンセリン & 80.7 & \pm & $20.7^{\mathrm{b}}$ & 5.6 & 114.8 & \pm & $16.3^{\mathrm{a}}$ & 3.3 & 110.2 & \pm & $3.5^{\mathrm{ab}}$ & 5.0 & 101.9 & 21.5 & 4.3 \\
\hline アルギニン & 50.7 & \pm & $23.6^{\mathrm{b}}$ & 3.5 & 72.4 & \pm & $22.7^{\mathrm{b}}$ & 2.1 & 239.1 & \pm & $28.6^{\mathrm{a}}$ & 10.8 & 120.7 & 87.8 & 5.1 \\
\hline プロリン & 61.6 & \pm & $13.1^{\mathrm{b}}$ & 4.3 & 150.3 & \pm & $26.9^{\mathrm{a}}$ & 4.3 & 66.4 & \pm & $2.2^{\mathrm{b}}$ & 3.0 & 92.8 & 44.3 & 3.9 \\
\hline 分岐鎖アミノ酸6) & 215.0 & \pm & $43.1^{\mathrm{b}}$ & & 714.1 & \pm & $176.3^{\text {a }}$ & & 348.3 & \pm & $40.5^{\mathrm{b}}$ & & 425.8 & $\pm \quad 236.7$ & \\
\hline 総量 & 1445.6 & \pm & $222.5^{\mathrm{c}}$ & 100.0 & 3488.4 & \pm & $608.5^{\mathrm{a}}$ & 100.0 & 2218.9 & \pm & $131.4^{\mathrm{b}}$ & 100.0 & 2384.4 & $\pm \quad 904.1$ & 100.0 \\
\hline & イワシ & $(\mathrm{n}=$ & $5)^{11}$ & & サンマ & $(\mathrm{n}=$ & $=5)^{2\rangle}$ & & アジ & $(\mathrm{n}=5$ & $5)^{2)}$ & & & & \\
\hline & $\mathrm{AV}$ & \pm & $\mathrm{SE}$ & $(\%)$ & $\mathrm{AV}$ & \pm & $\mathrm{SE}$ & $(\%)$ & $\mathrm{AV}$ & \pm & $\mathrm{SE}$ & (\%) & & & \\
\hline タウリン & 327.5 & \pm & 37.6 & 6.9 & 178.1 & \pm & 11.9 & 10.1 & 222.4 & \pm & 15.6 & 14.6 & & & \\
\hline アスパラギン酸 & 158.0 & \pm & 27.5 & 3.3 & 5.2 & \pm & 2.6 & 0.3 & 4.9 & \pm & 6.0 & 0.3 & & & \\
\hline スレオニン & 135.1 & \pm & 17.1 & 2.8 & 10.9 & \pm & 1.6 & 0.6 & 22.4 & \pm & 6.6 & 1.5 & & & \\
\hline セリン & 145.3 & \pm & 18.5 & 3.1 & 12.5 & \pm & 1.8 & 0.7 & 18.5 & \pm & 8.0 & 1.2 & & & \\
\hline グルタミン酸 & 273.3 & \pm & 42.6 & 5.7 & 32.4 & \pm & 5.4 & 1.8 & 55.5 & \pm & 13.6 & 3.6 & & & \\
\hline グルタミン & 32.9 & \pm & 4.6 & 0.7 & 4.5 & \pm & 0.7 & 0.3 & 4.1 & \pm & 1.6 & 0.3 & & & \\
\hline グリシン & 98.1 & \pm & 12.8 & 2.1 & 20.4 & \pm & 1.9 & 1.2 & 30.3 & \pm & 6.5 & 2.0 & & & \\
\hline アラニン & 296.3 & \pm & 32.3 & 6.2 & 42.5 & \pm & 6.3 & 2.4 & 61.2 & \pm & 10.7 & 4.0 & & & \\
\hline バリン & 183.8 & \pm & 23.8 & 3.9 & 17.9 & \pm & 2.1 & 1.0 & 21.7 & \pm & 8.7 & 1.4 & & & \\
\hline メチオニン & 127.2 & \pm & 17.4 & 2.7 & 7.1 & \pm & 1.2 & 0.4 & 13.2 & \pm & 4.7 & 0.9 & & & \\
\hline イソロイシン & 161.5 & \pm & 21.6 & 3.4 & 10.2 & \pm & 1.5 & 0.6 & 12.1 & \pm & 6.3 & 0.8 & & & \\
\hline ロイシン & 322.5 & \pm & 44.4 & 6.8 & 18.3 & \pm & 2.7 & 1.0 & 21.8 & \pm & 11.8 & 1.4 & & & \\
\hline チロシン & 154.8 & \pm & 21.2 & 3.3 & 11.0 & \pm & 1.8 & 0.6 & 15.1 & \pm & 6.4 & 1.0 & & & \\
\hline フェニルアラニン & 182.9 & \pm & 25.8 & 3.8 & 10.6 & \pm & 1.5 & 0.6 & 14.9 & \pm & 6.2 & 1.0 & & & \\
\hline$\beta$-アラニン & & $\operatorname{tr}$ & & & 1.1 & \pm & 0.6 & 0.1 & 1.2 & \pm & 0.7 & 0.1 & & & \\
\hline$\gamma$-アミノ酪酸 & 11.8 & \pm & 2.4 & 0.2 & 0.1 & \pm & 0.3 & 0.0 & 1.0 & \pm & 0.1 & 0.1 & & & \\
\hline オルニチン & 28.9 & \pm & 3.8 & 0.6 & 3.0 & \pm & 1.0 & 0.2 & 6.0 & \pm & 5.0 & 0.4 & & & \\
\hline リジン & 345.0 & \pm & 50.9 & 7.2 & 29.0 & \pm & 7.0 & 1.6 & 39.0 & \pm & 25.1 & 2.6 & & & \\
\hline 1-メチルヒスチジン & & $\operatorname{tr}$ & & & & $\operatorname{tr}$ & & & & $\operatorname{tr}$ & & & & & \\
\hline ヒスチジン & 1327.4 & \pm & 135.4 & 27.9 & 1337.6 & \pm & 111.0 & 75.6 & 919.8 & \pm & 133.2 & 60.3 & & & \\
\hline アンセリン & 98.7 & \pm & 20.7 & 2.1 & & $\operatorname{tr}$ & & & 9.9 & \pm & 16.6 & 0.7 & & & \\
\hline アルギニン & 224.0 & \pm & 34.2 & 4.7 & 8.4 & \pm & 2.5 & 0.5 & 17.6 & \pm & 9.6 & 1.2 & & & \\
\hline プロリン & 128.3 & \pm & 15.2 & 2.7 & 9.0 & \pm & 0.9 & 0.5 & 12.6 & \pm & 5.3 & 0.8 & & & \\
\hline 分岐鎖アミノ酸6) & 667.9 & \pm & 89.7 & & 46.4 & \pm & 0.5 & & 55.5 & \pm & 26.8 & & & & \\
\hline 総量 & 4763.4 & \pm & 589.4 & 100.0 & 1769.9 & \pm & 107.0 & 100.0 & 1525.3 & \pm & 176.6 & 100.0 & & & \\
\hline 魚体全体を試料として分 & & & & & & & & & & & & & & & \\
\hline ）頭と内臟を除去して分析 & & & & & & & & & & & & & & & \\
\hline 3) 平均土標準偏差 & & & & & & & & & & & & & & & \\
\hline 4）遊雁アミノ酸総量に占め & アミノ酸○ & 》割合 & を示す & & & & & & & & & & & & \\
\hline a, b, c の異なった記号は & カリの漁獲 & 桻海域! & に执いて有意差力 & ることを & $(\mathbf{p}<0$ & & & & & & & & & & \\
\hline , & 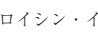 & & 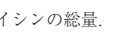 & & & & & & & & & & & & \\
\hline
\end{tabular}




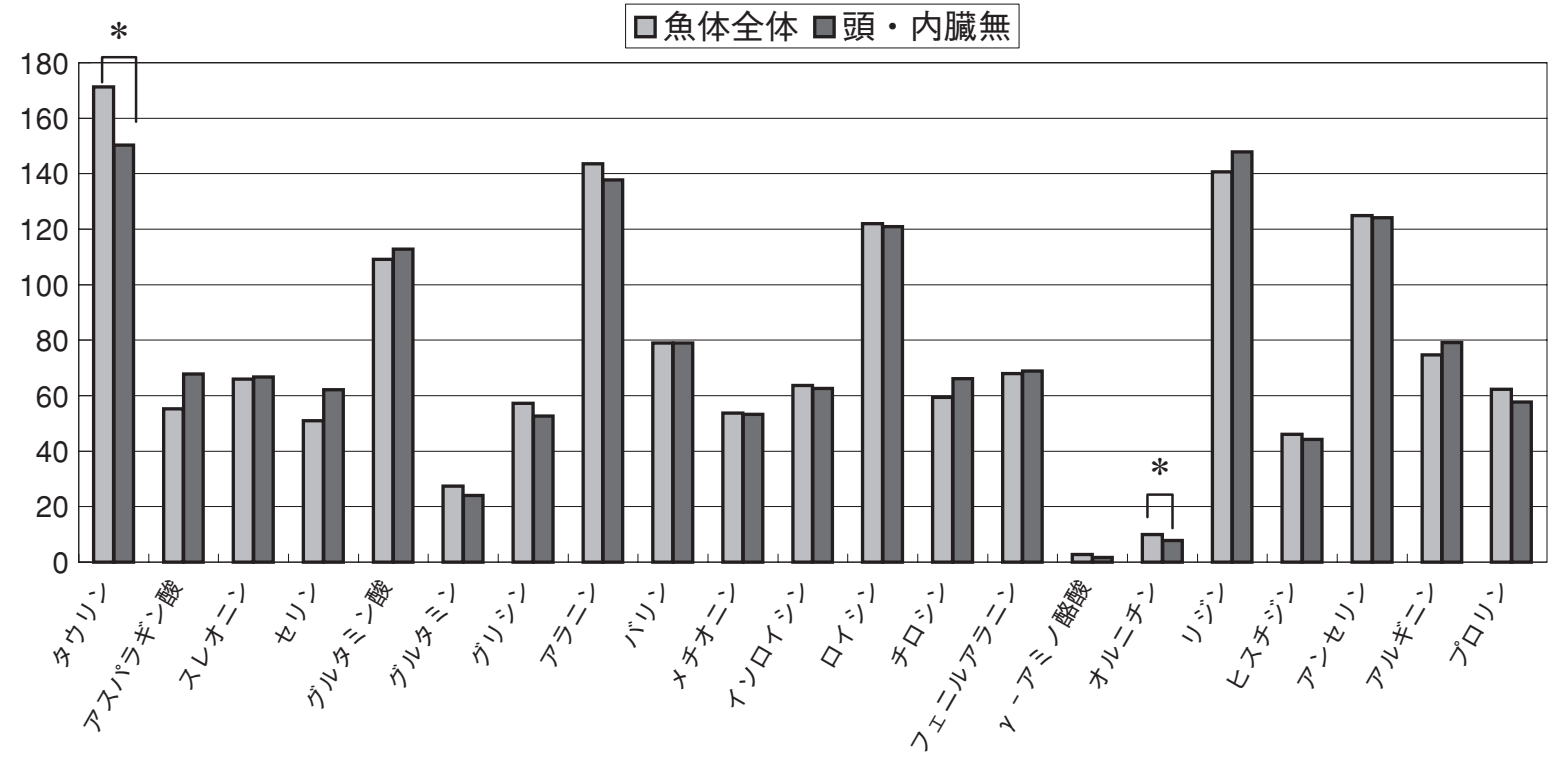

*対応するアミノ酸において頭および内臓の有無により有意差のあることを示す $(\mathrm{p}<0.05))$

図 1 メヒカリの頭および内臓の有無による遊離アミノ酸の差異 (mg/100g dry matter basis)

表 6 調理によるメヒカリ ${ }^{1)}$ の遊離アミノ酸組成（mg/100 $\mathrm{g}$ 除水分除脂肪）

\begin{tabular}{|c|c|c|c|c|c|c|c|c|c|}
\hline \multirow[b]{2}{*}{ タウリン } & \multicolumn{3}{|c|}{ 素揚げ } & \multicolumn{3}{|c|}{ 電子レンジ } & \multicolumn{3}{|c|}{ オーブン } \\
\hline & 231.70 & \pm & $18.13^{2)}$ ab3) & 244.90 & \pm & $13.41^{\mathrm{a}}$ & 212.30 & \pm & $12.12^{b}$ \\
\hline アスパラギン酸 & 85.71 & \pm & 4.34 & 84.42 & \pm & 20.74 & 74.19 & \pm & 17.18 \\
\hline スレオニン & 94.91 & \pm & 5.50 & 98.36 & \pm & 12.79 & 86.16 & \pm & 17.31 \\
\hline セリン & 80.26 & \pm & 5.77 & 75.26 & \pm & 14.32 & 66.37 & \pm & 12.18 \\
\hline グルタミン酸 & 159.14 & \pm & 6.49 & 166.40 & \pm & 18.51 & 148.98 & \pm & 23.95 \\
\hline グルタミン & 30.12 & \pm & 2.82 & 34.57 & \pm & 4.43 & 30.48 & \pm & 8.55 \\
\hline グリシン & 77.69 & \pm & 7.21 & 82.97 & \pm & 7.59 & 72.67 & \pm & 6.40 \\
\hline アラニン & 190.60 & \pm & 13.63 & 202.74 & \pm & 16.53 & 188.96 & \pm & 26.08 \\
\hline バリン & 106.59 & \pm & 6.48 & 119.34 & \pm & 15.77 & 106.00 & \pm & 23.72 \\
\hline メチオニン & 70.11 & \pm & 2.40 & 79.62 & \pm & 12.73 & 70.24 & \pm & 17.66 \\
\hline イソロイシン & 85.10 & \pm & 3.22 & 96.17 & \pm & 14.33 & 84.83 & \pm & 21.69 \\
\hline ロイシン & 161.89 & \pm & 7.15 & 186.80 & \pm & 28.02 & 168.99 & \pm & 43.26 \\
\hline チロシン & 84.06 & \pm & 4.28 & 98.03 & \pm & 14.14 & 90.60 & \pm & 21.09 \\
\hline フェニルアラニン & 88.77 & \pm & 4.56 & 106.14 & \pm & 15.30 & 95.08 & \pm & 23.12 \\
\hline 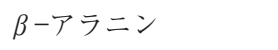 & 25.55 & \pm & 2.14 & 27.60 & \pm & 2.58 & 25.88 & \pm & 2.55 \\
\hline$\gamma-ア ミ ノ$ 酪酸 & 2.78 & \pm & 0.17 & 3.67 & \pm & 0.84 & 2.88 & \pm & 0.20 \\
\hline オルニチン & 10.74 & \pm & 1.22 & 16.33 & \pm & 4.92 & 11.77 & \pm & 2.64 \\
\hline リジン & 195.06 & \pm & 11.85 & 210.36 & \pm & 28.69 & 195.18 & \pm & 47.31 \\
\hline 1-メチルヒスチジン & 33.50 & \pm & 5.45 & 34.80 & \pm & 3.48 & 33.16 & \pm & 4.69 \\
\hline ヒスチジン & 54.67 & \pm & 4.18 & 60.61 & \pm & 4.92 & 54.98 & \pm & 4.29 \\
\hline アンセリン & 123.87 & \pm & 28.85 & 122.03 & \pm & 2.78 & 131.28 & \pm & 49.41 \\
\hline アルギニン & 107.68 & \pm & 18.04 & 127.28 & \pm & 14.96 & 128.38 & \pm & 21.81 \\
\hline プロリン & 82.50 & \pm & 4.25 & 88.56 & \pm & 11.68 & 71.92 & \pm & 12.30 \\
\hline 総量 & 2182.99 & \pm & 133.54 & 2366.95 & \pm & 235.99 & 2151.32 & \pm & 301.37 \\
\hline
\end{tabular}

1）魚体全体を調理に用いた。
2) 平均土標準偏差
3 ) a,bの異なった記号は調理法において有意差のあることを示す $(\mathrm{p}<0.05)$ 
臓能改善等が報告 ${ }^{10)}$ されている Tauは, メヒカリの漁 獲海域により $145.1 \mathrm{mg} \sim 276.8 \mathrm{mg} / 100 \mathrm{~g}$ (平均198.1mg) と変動がみられた。イワシ $327.5 \mathrm{mg}$ より低值であったが, サンマ178.1mg, アジ $222.4 \mathrm{mg}$ と同程度含有していた。

メヒカリの頭および内臓の有無による遊離アミノ酸組 成の差異を図 1 に示した。Tau, オルニチン（Orn）は, 頭と内臓を除去することにより低下し統計的に有意差が 見られた。Tau, Orn 以外のアミノ酸に有意な変動は見 られなかった。メヒカリは，1尾として魚体全体を食す ことにより Tau を有効に摂取出来ることが示された。

メヒカリの電子レンジ，オーブン，素揚げ調理による 遊離アミノ酸組成を表 6 , から揚げ，天ぷら，フライ調 理による遊離アミノ酸組成を表 7 に示した。

電子レンジ，オーブン，素揚げ調理による遊離アミノ 酸は, 電子レンジに比べてオーブン, 素揚げでAsp,

Ser, Ans, Arg 以外のアミノ酸が低值で遊離アミノ酸総 量も低值であった。特に Tauは, 統計的な有意差が認 められた。衣を付けた調理のから揚げ，天ぷら，フライ

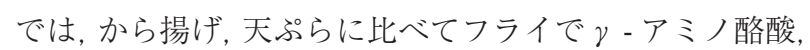

His, Asn, Arg 以外のアミノ酸が低值で遊離アミノ酸総 量も低值であった。特にTau, 1-メチルヒスチジン, Ser, Arg は統計的に有意な有意差が認められた。Tauは調理 や製造工程で溶出しやすいことが知られており ${ }^{19)}$, 本研 究の結果からも他のアミノ酸に比べて調理法による変動 が大きいことが示された。

\section{3 ）メヒカリの脂質中の脂肪酸組成}

魚類の脂質中の主な脂肪酸組成を表 8 に示した。メヒ カリのそれぞれの脂肪酸の割合は, 漁獲海域により統計 的に有意な差は認められたが脂肪酸組成パターンに大き な違いは見られなかった。メヒカリの脂肪酸組成パター ンは，周年大きな違いがないことが報告されている ${ }^{112)}$ 。 メヒカリの主要な脂肪酸は, パルミチン酸 (C16:0) が 約 $24 \%$ ，オレイン酸（C18:1）が約 $42 \%, \mathrm{EPA}$ が約 $6 \%$, DHA が約 $9 \%$ で，イワシ，アジは C16:0が最も高い割合 を示したのに対し,メヒカリは $\mathrm{C}_{18}: 1$ の割合が最も高かっ た。C18:1は，善玉の HDL-コレステロール濃度を低下 させずに血中総コレステロール濃度の低下作用を示すこ とが報告されている ${ }^{20)}$ 。 EPA は愛知県産に比べて常磐沖

表 7 調理によるメヒカリ ${ }^{1)}$ の遊離アミノ酸組成 $(\mathrm{mg} / 100 \mathrm{~g}$ 除水分除脂肪 $)$

\begin{tabular}{|c|c|c|c|c|c|c|c|c|c|}
\hline \multirow[b]{2}{*}{ タウリン } & \multicolumn{3}{|c|}{ から揚げ } & \multicolumn{3}{|c|}{ 天ぷら } & \multicolumn{3}{|c|}{ フライ } \\
\hline & 138.4 & \pm & $10.2^{2)}$ ab 3$)$ & 150.8 & \pm & $17.7^{\mathrm{a}}$ & 122.8 & \pm & $12.9^{\mathrm{b}}$ \\
\hline アスパラギン酸 & 54.6 & \pm & 9.0 & 48.7 & \pm & 2.7 & 41.9 & \pm & 7.8 \\
\hline スレオニン & 54.7 & \pm & 5.1 & 51.8 & \pm & 10.4 & 49.1 & \pm & 7.4 \\
\hline セリン & 49.6 & \pm & $6.2^{\mathrm{a}}$ & 44.9 & \pm & $4.6^{\mathrm{ab}}$ & 38.0 & \pm & $5.9^{\mathrm{b}}$ \\
\hline グルタミン酸 & 86.5 & \pm & 9.8 & 91.3 & \pm & 17.1 & 83.0 & \pm & 13.1 \\
\hline グルタミン & 18.9 & \pm & 2.8 & 18.7 & \pm & 4.6 & 17.2 & \pm & 3.3 \\
\hline グリシン & 44.3 & \pm & 4.5 & 45.5 & \pm & 6.0 & 37.7 & \pm & 3.0 \\
\hline アラニン & 111.5 & \pm & 8.8 & 113.5 & \pm & 17.7 & 98.0 & \pm & 10.5 \\
\hline バリン & 64.5 & \pm & 6.0 & 63.2 & \pm & 14.4 & 56.5 & \pm & 9.4 \\
\hline メチオニン & 41.0 & \pm & 5.1 & 39.6 & \pm & 10.8 & 36.5 & \pm & 6.6 \\
\hline イソロイシン & 50.6 & \pm & 5.9 & 48.3 & \pm & 12.9 & 46.0 & \pm & 8.7 \\
\hline ロイシン & 98.0 & \pm & 11.9 & 93.2 & \pm & 24.8 & 87.7 & \pm & 16.7 \\
\hline チロシン & 54.8 & \pm & 6.6 & 51.0 & \pm & 9.9 & 45.5 & \pm & 6.4 \\
\hline フェニルアラニン & 55.0 & \pm & 6.8 & 53.0 & \pm & 13.8 & 49.6 & \pm & 8.5 \\
\hline$\beta$-アラニン & 15.0 & \pm & 2.0 & 15.6 & \pm & 1.3 & 12.0 & \pm & 2.4 \\
\hline$\gamma-ア ミ ノ$ 酪酸 & 1.7 & \pm & 0.2 & 2.0 & \pm & 0.3 & 2.2 & \pm & 0.3 \\
\hline オルニチン & 7.3 & \pm & 1.0 & 7.5 & \pm & 3.3 & 7.0 & \pm & 1.1 \\
\hline リジン & 121.4 & \pm & 14.7 & 122.2 & \pm & 35.8 & 101.6 & \pm & 15.7 \\
\hline 1-メチルヒスチジン & 18.2 & \pm & $2.8^{\mathrm{ab}}$ & 19.7 & \pm & $1.5^{\mathrm{a}}$ & 13.4 & \pm & $2.9^{\mathrm{b}}$ \\
\hline ヒスチジン & 31.8 & \pm & 3.5 & 36.6 & \pm & 11.3 & 32.8 & \pm & 8.3 \\
\hline アンセリン & 71.7 & \pm & 7.6 & 102.0 & \pm & 41.7 & 75.7 & \pm & 9.4 \\
\hline アルギニン & 77.4 & \pm & $11.0^{\mathrm{ab}}$ & 78.9 & \pm & $14.0^{\mathrm{a}}$ & 56.0 & \pm & $5.9^{\mathrm{b}}$ \\
\hline プロリン & 50.6 & \pm & 5.2 & 45.9 & \pm & 7.7 & 45.9 & \pm & 4.4 \\
\hline 総量 & 1317.6 & \pm & 127.7 & 1343.9 & \pm & 235.1 & 1156.2 & \pm & 147.9 \\
\hline
\end{tabular}

1）魚体全体を調理に用いた。

2) 平均土標準偏差

3 ） a,bの異なった記号は調理法において有意差のあることを示す（p＜0.05） 
日本食生活学会誌 Vol.20 No.3（2009）

表 8 魚類の脂質中の脂肪酸組成（\%)

\begin{tabular}{|c|c|c|c|c|c|c|c|c|c|c|c|c|}
\hline \multirow[b]{3}{*}{$\mathrm{C}_{14: 0}$} & \multicolumn{10}{|c|}{ メヒカリ1) } & \multirow{3}{*}{$\begin{array}{r}\text { イワシ }{ }^{2)} \\
9.8\end{array}$} & \multirow{3}{*}{$\frac{\text { アジ2) }}{4.4}$} \\
\hline & \multicolumn{3}{|c|}{ 愛知県産 $(\mathrm{n}=5)$} & \multicolumn{3}{|c|}{ 宮崎県産(n=5) } & \multicolumn{3}{|c|}{ 常磐沖産 (n= 5 ) } & \multirow{2}{*}{$\begin{array}{r}\text { 平均 }(\mathrm{n}=15) \\
4.6\end{array}$} & & \\
\hline & 4.5 & \pm & $0.2^{3) \mathbf{b} 4)}$ & 5.0 & \pm & $0.2^{\mathrm{a}}$ & 4.3 & \pm & $0.2^{\mathrm{b}}$ & & & \\
\hline $\mathrm{C}_{16: 0}$ & 22.7 & \pm & $0.6^{\mathrm{b}}$ & 25.1 & \pm & $0.6^{\mathrm{a}}$ & 22.6 & \pm & $0.7^{\mathrm{b}}$ & 23.5 & 24.7 & 32.5 \\
\hline $\mathrm{C}_{16: 1}$ & 5.0 & \pm & $0.4^{\mathrm{b}}$ & 6.8 & \pm & $0.4^{\mathrm{a}}$ & 4.7 & \pm & $0.4^{\mathrm{b}}$ & 5.5 & 11.6 & 9.1 \\
\hline $\mathrm{C}_{18: 0}$ & 3.9 & \pm & $0.3^{\mathrm{b}}$ & 4.6 & \pm & $0.1^{\text {a }}$ & 4.0 & \pm & $0.2^{\mathrm{b}}$ & 2.2 & 3.2 & 5.6 \\
\hline $\mathrm{C}_{18: 1}$ & 46.8 & \pm & $0.9^{\text {a }}$ & 36.5 & \pm & $2.6^{\mathrm{b}}$ & 43.9 & \pm & $2.3^{\mathrm{a}}$ & 42.4 & 11.3 & 20.9 \\
\hline $\mathrm{C}_{18: 2}$ & 0.4 & \pm & 0.1 & 0.6 & \pm & 0.1 & 0.5 & \pm & 0.1 & 0.3 & 5.9 & 0.9 \\
\hline $\mathrm{C}_{18: 3}$ & & $\operatorname{tr}$ & & & $\operatorname{tr}$ & & & $\operatorname{tr}$ & & $\operatorname{tr}$ & $\operatorname{tr}$ & 2.0 \\
\hline $\mathrm{C}_{20: 1}$ & 2.8 & \pm & 0.2 & 2.5 & \pm & 0.1 & 2.7 & \pm & 0.4 & 2.7 & 2.6 & 0.6 \\
\hline $\mathrm{C}_{20: 4}$ & 1.2 & \pm & $0.4^{\mathrm{ab}}$ & 1.4 & \pm & $0.2^{\mathrm{a}}$ & 0.9 & \pm & $0.04^{\mathrm{b}}$ & 1.2 & $\operatorname{tr}$ & 2.5 \\
\hline $\mathrm{C}_{20: 5}$ & 4.6 & \pm & $0.3^{b}$ & 6.2 & \pm & $0.8^{\mathrm{a}}$ & 7.1 & \pm & $0.2^{\mathrm{a}}$ & 6.0 & 22.2 & 7.0 \\
\hline $\mathrm{C}_{22: 6}$ & 7.4 & \pm & $0.3^{b}$ & 10.3 & \pm & $1.3^{\mathrm{a}}$ & 8.4 & \pm & $0.7^{\mathrm{b}}$ & 8.7 & 5.5 & 13.2 \\
\hline
\end{tabular}

1）魚体全体を試料として分析した

2 ）頭と内臟を除去し分析した

3 ) 平均土標準偏差

4）a, b, c の異なった記号はメヒカリの漁獲海域において有意差があることを示す（p＜0.05）

産，宮崎県産が高く，常磐沖産，宮崎県産ではアジと同 程度の割合であった。DHA は愛知県産, 常磐沖産に比 べて宮崎県産が高かったが, どの漁獲海域においてもイ ワシより高い割合であった。EPA, DHAには，血中脂質 低下作用・血管梗塞性疾病予防作用等が報告され4) 5) 20), さらにDHA についてはアルツハイマー型認知症予防や 改善効果, 脳の発達する時期（乳児期）における栄養成 分としての重要性を示す報告 ${ }^{21)}$ もる。しかし， EPA やDHA などの高度不飽和脂肪酸は熱や光により極めて 酸化されやすく油焼けをおこしやすい21) ことから，魚の 干物や塩蔵品などで長時間貯蔵されたものには注意し, 新鮮な魚を摂取することが望まれる。

\section{4. 要約}

福島県いわき市の「市の魚」に制定されたメヒカリは, 青森から鹿児島県にいたる大陸棚の比較的深いところに 分布している小型魚で, 肉質は白身であり魚肉, 骨とも に脆弱であることから魚体全体を食されることが多い。 そこで, 漁獲海域の異なるメヒカリ（愛知県産, 宮崎県 産, 常磐沖産）を用いて, メヒカリ（魚体全体）の栄養 成分について検討した。

(1) 水分は66.6〜 75.2\%, タンパク質は14.2〜 $15.8 \%$, 脂質は5.4〜 $14.9 \%$ ，灰分は $2.6 〜 3.6 \%$ で，特に脂質 含量は漁獲海域により変動が見られた。

(2) 制限アミノ酸はトリプトファンで, アミノ酸スコア は83であった。

(3) 主要な遊離アミノ酸は Lys, Tau, Ala, Leu, Gluで あったが, 遊離アミノ酸総量は漁獲海域により差が見 られた。Tauは，他のアミノ酸に比べて調理による変 動が大きかった。

(4) 脂肪中の主な脂肪酸組成は, C $16: 0$ が約 $24 \%, \mathrm{C} 18: 1$ が
約 $42 \%, \mathrm{C}_{20}: 5$ (EPA) が約 $6 \%$ C $22: 6$ (DHA) が約 $9 \%$ で, C18：1の割合が高かった。

(5) 魚体全体に対して, 頭と内臓を除去することにより コレステロールとタウリンの含量はそれぞれ低下した。

\section{引用文献}

1) Iso H., Kobayashi M., Ishihara J., Sasaki S., Okada K., Kita Y., Kokubo Y., Tsugane S.: JPHC Study Group. Intake of Fish and $n 3$ Fatty Acids and Risk of Coronary Heart Disease Among Japanese : The Japan Public Health Center-Based (JPHC) Study Cohort I , Circulation., 113, 195-202 (2006)

2) 平山 雄: 魚食と健康一魚介類摂取頻度別にみた死因別 死亡率一, 中外医薬，45: 157-162（1992）

3 ) Yamagishi K., Iso H., Date C., Fukui M., Wakai K., Kikuchi S., Inaba Y., Tanabe N. and Tamakoshi A.: Japan Collaborative Cohort Study for Evaluation of Cancer Risk Study Group, Fish, $\omega-3$ Polyunsaturated Fatty Acids, and Mortality from Cardiovascular Diseases in a Nationwide Community-Based Cohort of Japanese Man and Women, 52, 988-996 (2008)

4 ) Iso, H., Rexrode, K. M., Stampfer, M. J., Manson, J. E., Colditz, C. A., Speizer, F. E., Hennekens, C. H. and Willett W. W.: Intake of Fish and Omega- 3 Fatty Acid and Risk of Stroke in Women, J. Am. Med. Assoc., 285: 304-312, 2001.

5 ) Siratori C. R., Crepaldi G., Manzato E., Mancini M., Rivellese A., Paoletti R., Pazzucconi F., Pamparana F. and Stragliotto E.: One-year Treatment with Ethyl Esters of n- 3 Fatty Acids in Patients with Hypertriglyceridemia and Glucose Intolerance Reduced Triglyceridemia, Total Cholesterol and Increased HDL-C without Glycemic Alterations, Atherosclerosis, 137, 419-429 (1998)

6 ) 福島県農林水産部水産課, 福島県海面漁業漁獲高統計 平成19年度版, pp83（2007）

7 ）日本食品科学工学会委員会: 新. 食品分析法, 光琳, 東京, pp 6-9 , 40-43, 99-101 (1982)

8 ) Folch, J., Mlees, M., and Sloane Stanley, G.H.,: A Simple 
Method for the Isolation and Purification of Total Lipids from Animal Tissus, J. Biol. Chem., 226, 497-509 (1957)

9) Zak B.: Simple Rapid Microtechnic for Serum Total Cholesterol, Am. J. Clin. Pathol., 27, 583-588（1956）

10）鈴木平光, 和田 俊, 三浦理代: 水産食品栄養学一基礎 からヒトへ一, 技報堂出版, 東京, pp 7-19, pp244-245, pp271-288 (2004)

11）財団法人ふくしま海洋科学館：「いわき市の魚・めひか り」生態基礎調査 -2 (2004)

12）財団法人ふくしま海洋科学館：「いわき市の魚・めひかり」 生態基礎調査 -3 （2005）

13）久留亜希子, 落合芳博: 茨城県産魚類の筋肉成分組成の 季節変化, 茨城大教育学部紀要, 43：109-119（1994）

14）鴻巣章二監修:魚の科学, 朝倉書店, 東京, pp 1-11 (1996)

15）佐々木恵一, 県有用水産物の優位性の解明に関する研究 県産主要魚類の一般成分, 福島県水産試験場事業報告書
2006, 60-61 (2007)

16）鈴木継美, 和田 攻: ミネラル・微量元素の栄養学, 第 一出版, 東京, 1994, pp123-125. pp174-175. pp367-370. 厚 生労働省策定: 日本人の食事摂取基準 (2005年版), 第一出版, 東京, pp.50-68 (2005)

17） (株日本必須アミノ酸協会編: タンパク質・アミノ酸の科学 工業調查会, 東京, pp212-228（2007）

18）鴻巣章二, 須山三千三編 : 水産食品学. 恒星社厚生閣, 東京, pp35-37, pp67-68 (1991)

19）笠岡（坪山）宜代: 魚介類の効果一魚油, タウリンを中 心として一，臨床栄養，109，299-306（2006）

20）竹内弘幸: 高度不飽和脂肪酸とオレイン酸の健康栄養機能, オレオサイエンス， 7 (10)：391-397（2007）

21）藤本健四郎：魚の脂質の特徵と食品機能, 日本調理科学 会誌，39:271-276（2006） 